\title{
QUALITY OF EGGS FOR CONSUMPTION FROM DIFFERENT PRODUCERS IN THE MARKETS IN REPUBLIC OF MACEDONIA. 1: EGG MASS AND EGG SHELL STRENGTH
}

\author{
Dragoslav Kocevski ${ }^{1}$, Nedeljka Nikolova ${ }^{2}$, Gjoko Bunevski ${ }^{1}$, Vladimir Džabirski ${ }^{1}$, \\ Vlado Vuković ${ }^{1}$, Kočo Porču ${ }^{1}$ \\ ${ }^{1}$ Faculty for Agricultural Science and Food, "Ss. Cyril and Methodius" University in Skopje, \\ Blvd. Aleksandar Makedonski bb, 1000 Skopje, Republic of Macedonia \\ ${ }^{2}$ Institute of Animal Science, "Ss. Cyril and Methodius" University in Skopje, \\ Blvd. Ilinden 92A, 1000 Skopje, Republic of Macedonia \\ Dragoslav.Kocevski@yahoo.com
}

\begin{abstract}
Eggs as a high valued nutrition product with acceptable price are required on the market, and therefore regular control of their quality is necessity. The aim of this trial was to monitor some quality parameters in eggs for consumption: egg (weight) mass and egg shell quality in M, L and XL weight classes produced by different producers, therefore confirming their marketing quality. From different markets in the region of Skopje, eggs from $\mathrm{M}, \mathrm{L}$ and XL classes were purchased as different brands mostly present on the Macedonian market. Eggs were analyzed the same day. Egg quality was analyzed using computerized equipment for measuring egg shell strength (Eggshell Force Gauge) and automatic machine Egg Multi Tester EMT 5200 for measuring of the internal egg quality (Robotmation Co. Ltd., Tokyo, Japan). It was noticed that eggs in L and XL weight classes were mixed with eggs weighting less than the minimum weight for these classes, or more preciselly in L class eggs several pieces of $\mathrm{M}$ weight classs were notified and in XL weight class some percent of L class eggs were monitored. Only 20 sampless (26.66\%) of M class eggs had sufficient value for egg shell strength, while in 110 analyzed samples of L class only 35 samples (30.43\%) fulfill required egg shell strength. Eggs from analyzed brands in general do not fulfill required marketing quality in respect to the analyzed parameters: egg mass and egg shell strength of the eggs for consumption.
\end{abstract}

Key words: brands; eggs for consumption; markets; egg mass; egg shell strength

\section{КВАЛИТЕТ НА КОНСУМНИТЕ ЈАЈЦА ОД РАЗЛИЧНИ ПРОИЗВОДИТЕЛИ ВО МАРКЕТИТЕ ВО РЕПУБЛИКА. МАКЕДОНИЈА 1: МАСА НА ЈАЈЦАТА И ЦВРСТИНА НА ЛУШПАТА}

\begin{abstract}
Јајцата како високовреден прехранбен производ со прифатлива цена се доста барани на пазарот, заради што е неопходна редовна контрола на нивниот квалитет. Целта на овој труд беше да се испитаат некои параметри на квалитетот на консумните јајца: масата на јајцата и цврстината на лушпата на јајца означени како класа $\mathrm{M}, \mathrm{L}$ и $\mathrm{XL}$, произведени од различни производители, за да се утврди нивниот пазарен квалитет. На подрачјето на градот Скопје во различни маркети се купени јајца од класите M, L и XL од 10 различни производители - застапени на македонскиот пазар. Јајцата се анализирани истиот ден. Квалитетот на јајцата беше испитуван со помош на автоматизирана машина за мерење на цврстината на лушпата на јајцата (Eggshell Force Gauge) и автоматизирана машина (Egg Multi Tester EMT 5200) за мерење на внатрешниот квалитет на јајцата (Robotmation Co. Ltd., Tokyo, Japan). Кај јајцата од тежинските класи L и XL е забележано мешање на јајца со помала маса од минималната пропишана за овие класи во пакувањата, односно во пакувањата од тежинската класа L се детерминирани одреден процент јајца од тежинската класа M, а во пакувањата од тежинската класа XL се детерминирани одреден процент јајца од тежинската класа L. Само 20 примероци (26.66\%) од јајцата од класата М беа со задоволителна вредност за цврстината на лушпата, додека од вкупно анализираните 110 примероци од класата L бараната цврстина ја имале само 35 примероци $(30,43 \%)$. Консумните јајца од испитуваните производители генерално не го задоволуваат бараниот пазарен квалитет во однос на испитуваните параметри - масата на јајцата и цврстината на лушпата.
\end{abstract}

Клучни зборови: бренд; консумни јајца; маркети; маса на јајца, цврстина на лушпа 


\section{INTRODUCTION}

Eggs are product from poultry that present excellent source of high valued proteins, fats (phospholipids and unsaturated fatty acids), vitamins and minerals [18]. That is the reason that eggs take primary place in the human nutrition and as such they should be properly keep, but due to the acceptable price and high market demands it is necessary to perform regular quality control of the offered eggs [5]. Egg quality of the eggs intended for market is controlled through several important characteristics, that are defined or recommended in the Law for Quality of Agricultural Products, Chapter 1 "Market organization", part 4 "Market organization for poultry meat and eggs" [8], addition of this law [16 and 7] as well as escorting Rulebook for way of marking the eggs intended for market and eggs for incubation, marks and their use [16]. These laws and Rulebook define marketing and regulate: names, definitions and general terms for collecting, grading, marking, small and big packages, holding, data collecting for production and control of the quality of the eggs for consumption.

In the Law under the definition „eggs" mean shell eggs produced from Gallus gallus species, intended for human consumption or use in the egg product industry, food production or processing industry, except broken eggs, incubated and boiled eggs. According the mentioned law for quality of agricultural products, on the market in R. of Macedonia only A grade eggs could be marketed according the quality (freshness). These eggs in the marketing are declared and marked as fresh and has a Hough units values higher than 55 .

Additionally fresh eggs are graded according the size (weight) in several grades, which are priced accordingly. Eggs intended for market are graded according the quality on A grade eggs or fresh eggs and B grade eggs intended for processing in the industry. Eggs of A grade are further graded according the weight in four grades XL, L, $\mathrm{M}$, and S (Table 1). Quality of eggs is controlled through measuring of the of external and internal egg characteristics.

Most often analyzed characteristics of the egg quality are egg shape index, strength and thickness of the shell, air sack height, albumen and yolk clearness, yolk color, $\mathrm{pH}$ values for albumen and yolk, albumen height and Hough units [15].

It was reported [1] for significant influence of the age on the egg size (weight) in the Leghorn layers. Quality of the egg shell is presented thro- ugh the weight and strength of the egg shell. Egg weight has direct influence on egg size and shell thickness [6]. Age of hens is factor of influence on the egg size. Many authors [13, 19, 11, 20, 14, 3] showed that egg weight has been significantly increased with increased age of the layers, contrary to the [21] that reported the opposite.

\section{Table 1}

Eggs grading according the size (weight) based on the newly adopted EU method

\begin{tabular}{lll}
\hline Egg size (weight) & EU mark & MK mark \\
\hline Over 73 g & XL (Extra large) & Супер големи \\
Less than 73-63 g & L- Large & Големи \\
Less than 63-53g & $\mathrm{M}$ - Medium & Средни \\
Less than 53 g & $\mathrm{S}$-Small & Мали \\
\hline \hline
\end{tabular}

According previously mentioned goal of this research was to investigate some parameters of the quality of eggs for consumption: egg weight and shell strength in eggs marked as M, L and XL offered from different producers (brands), in order to reconfirm their declared marketing quality.

\section{MATERIAL AND METHODS}

In order to analyze the weight and shell strength of the eggs for consumption in the region of city of Skopje eggs of different weight grades (M, L and XL) from 10 different producers (brands 1 - 10) were purchased in different markets. Total of 205 eggs of the mentioned weight grades are analyzed, presented in the markets by 10 brands that are offerings eggs for consumption on the Macedonian market. Eggs were kept on the refrigerated shelf on the temperature lower than $5^{\circ} \mathrm{C}$ and were purchased and analyzed in November 2013. Brands were represented by different number of eggs as presented in the Table 2.

Analyses are realized in the laboratory for control of the marketing quality of the eggs at the Institute for Animal Biotechnology at the Faculty for Agricultural Science and Food of the University „Sts. Cyril and Methodius“ in Skopje, using automatic machine for measuring the shell strength (Eggshell Force Gauge) and automatic machine (Egg Multi Tester EMT 5200) for measuring the internal egg quality (egg weight in grams, albumen height, Hough units, yolk color and egg quality grade). 
Table 2

Number of analyzed egg samples with indicative date of production and declared date "best before"

\begin{tabular}{|c|c|c|c|c|c|c|c|c|c|}
\hline \multirow[t]{2}{*}{ Brands } & \multicolumn{3}{|c|}{$\begin{array}{c}\text { Number of } \\
\text { analyzed samples }\end{array}$} & \multicolumn{3}{|c|}{$\begin{array}{l}\text { End date of use presented on the packing } \\
\text { ( } 28 \text { days after laying) }\end{array}$} & \multicolumn{3}{|c|}{ Indicative date of production* } \\
\hline & $\mathrm{M}$ & $\mathrm{L}$ & XL & M & $\mathrm{L}$ & $\mathrm{XL}$ & M & $\mathrm{L}$ & XL \\
\hline 1 & 10 & 10 & 0 & 17-Dec-13 & 15-Dec-13 & & 19-Nov-13 & 17-Nov-13 & \\
\hline 2 & 10 & 10 & 0 & 12-Dec-13 & 12-Dec-13 & & 14-Nov-13 & 14-Nov-13 & \\
\hline 3 & 10 & 10 & 0 & 10-Dec-13 & 10-Dec-13 & & 12-Nov-13 & 12-Nov-13 & \\
\hline 4 & 10 & 10 & 0 & 26-Nov-13 & 4-Dec-13 & & 29-Oct-13 & 6-Nov-13 & \\
\hline 5 & 10 & 10 & 10 & 10-Dec-13 & 29-Nov-13 & 29-Nov-13 & 12-Nov-13 & 1-Nov-13 & 1-Nov-13 \\
\hline 6 & 10 & 10 & 10 & \multirow[t]{4}{*}{ 10-Dec-13 } & 4-Dec-13 & \multirow[t]{6}{*}{ 4-Dec-13 } & \multirow[t]{4}{*}{ 12-Nov-13 } & 6-Nov-13 & \multirow[t]{6}{*}{ 6-Nov-13 } \\
\hline 7 & 0 & 15 & 0 & & 3-Dec-13 & & & 5-Nov-13 & \\
\hline 8 & 0 & 10 & 0 & & 24-Dec-13 & & & 26-Nov-13 & \\
\hline 9 & 0 & 10 & 0 & & 15-Dec-13 & & & 17-Nov-13 & \\
\hline 10 & 15 & 15 & 0 & \multirow[t]{2}{*}{ 12-Dec-13 } & \multirow[t]{2}{*}{ 12-Dec-13 } & & \multirow[t]{2}{*}{ 14-Nov-13 } & \multirow[t]{2}{*}{ 14-Nov-13 } & \\
\hline Total: & 75 & 110 & 20 & & & & & & \\
\hline
\end{tabular}

* Date of production should be 28 before the presented end date for use and no more than $30-31$ days because eggs should be graded and packed no later than 10 days after the laying (because Saturday and Sunday - weekends and production during the weekends) and presented "best before" date is 28 after laying.

\section{RESULTS AND DISCUSSION}

Results from the egg weight analyses in three grades (M, L and XL) of 10 different brands are presented in Table 3. No significant deviations in egg weight and egg shell strength are notified in grade $\mathrm{M}$ eggs. Declared weight is in the standards for this grade $(53-63 \mathrm{~g})$. Egg shell strength is in range from 3275.50 to $4205.20 \mathrm{~g} / \mathrm{cm}^{2}$, the lowest in brand 2, and the highest in brand 5 .

Table 3

\begin{tabular}{ccc|cc||cc}
\multicolumn{8}{c}{ Analyzes of egg weight and egg shell strength in grades $M, L u X L$} \\
\hline \hline $\begin{array}{c}\text { Different } \\
\text { brands }\end{array}$ & $\begin{array}{c}\text { Ggg weight } \\
(\mathrm{g})\end{array}$ & $\begin{array}{c}\text { Shell strength } \\
\left(\mathrm{g} / \mathrm{cm}^{2}\right)\end{array}$ & $\begin{array}{c}\text { Egg weight } \\
(\mathrm{g})\end{array}$ & $\begin{array}{c}\text { Shade L } \\
\left(\mathrm{g} / \mathrm{cm}^{2}\right)\end{array}$ & $\begin{array}{c}\text { Grade XL } \\
(\mathrm{g})\end{array}$ & $\begin{array}{c}\text { Shell strength } \\
\left(\mathrm{g} / \mathrm{cm}^{2}\right)\end{array}$ \\
\hline 1 & 59.35 & 3741.10 & 63.20 & 4121.50 & 0.00 & 0.00 \\
2 & 58.97 & 3404.20 & 64.72 & 3269.50 & 0.00 & 0.00 \\
3 & 56.81 & 3275.50 & 65.39 & 3487.20 & 0.00 & 0.00 \\
4 & 62.62 & 3717.00 & 63.64 & 3397.80 & 0.00 & 0.00 \\
5 & 59.46 & 4205.20 & 62.04 & 3992.30 & 71.49 & 3583.40 \\
6 & 60.35 & 4030.00 & 66.30 & 3548.11 & 74.02 & 3440.40 \\
7 & 0.00 & 0.00 & 65.64 & 3987.80 & 0.00 & 0.00 \\
8 & 0.00 & 0.00 & 64.51 & 3562.10 & 0.00 & 0.00 \\
9 & 0.00 & 0.00 & 64.43 & 3551.50 & 0.00 & 0.00 \\
10 & 60.81 & 3603.27 & 64.45 & 3835.07 & 0.00 & 0.00 \\
\hline \hline
\end{tabular}

In the $\mathrm{M}$ grade eggs no mixing of lower classe eggs is notified meaning, that the consumers are not manipulated or have received the product that hey pay for according the adopted standards for weight for this grade (Graph 1). If we take in consideration that the egg shell strength is within 
the range $3850.00-4100.00 \mathrm{~g} / \mathrm{cm}^{2}$ [9], than eggs graded as $\mathrm{M}$ grade in average have only 20 out of 75 analyzed eggs. This means that only $26.66 \%$ of the eggs are within the declared or desired egg shell strength for the genetic provenience (Graph 2).

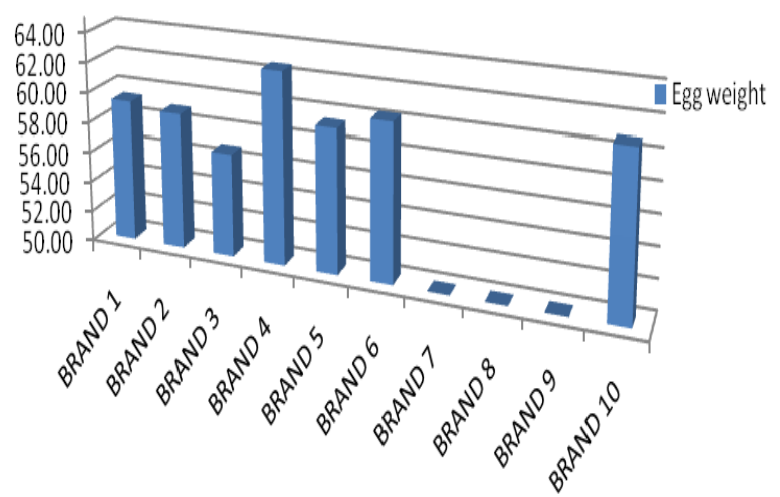

Graph. 1. Egg weight in M graded eggs from different brands

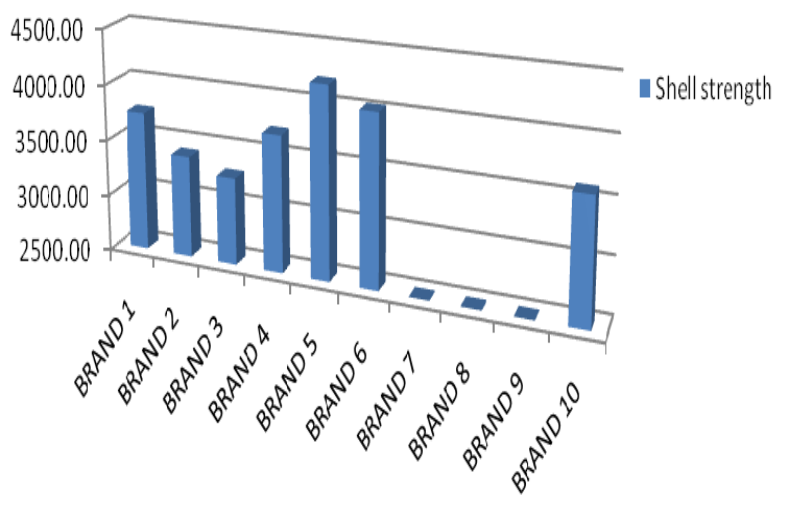

Graph. 2. Egg shell strength in M graded eggs from different brands

Analyses of the eggs graded as L weight grade show significant deviations regarding parameter - declared weight (that for this grade should be in the range of 63-73 g). In analyzed eggs from this grade, eggs from brand 5 had lower average weight than the minimal weight of 63 grams. In this grade eggs mixing of eggs of lower grade eggs was notified. More precisely eggs that should be graded as M grade were graded and packed in this, grade L.

This means that the packing centers has mixed the eggs from lower grade with the eggs from the higher grades (in this case L graded eggs in brand 1 is $50 \%$ (5 out of 10 eggs), brand 2 is $40 \%$ ( 4 out of 10 eggs), brand 3 is $20 \%$ ( 2 out of 10 eggs), brand 4 is $30 \%$ ( 3 out of 10 eggs), brand 5 is $40 \%$ ( 4 out of 10 eggs), brand 7 is $30 \%$ ( 3 out of 10 eggs), brand 8 is $20 \%$ ( 2 out of 10 eggs) and brand 9 also $20 \%$ ( 2 out of 10 eggs), with a goal to get additional income and profit from sales of lower grade eggs as higher graded eggs to the cheated consumers. Only in brand 6 and brand 10 results for all analyzed eggs in the package were in correspondence to the declared weight on the package (Graph 3).

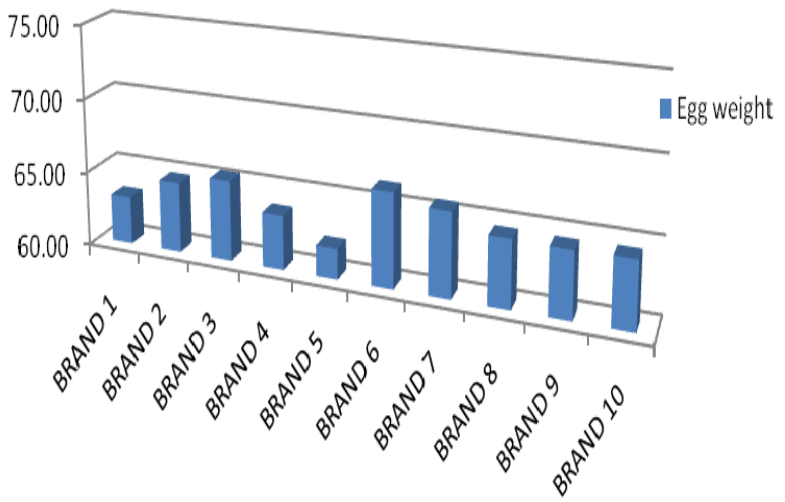

Graph. 3. Egg weight in M graded eggs from different brands

According already mentioned law for quality of agricultural products, such deviations, or more precisely presence of eggs from lower grades in the packages that should contain higher grades should not be more than $5 \%$ or if the sample is smaller than 180 eggs such deviation should be double or $10 \%$.

Egg shell strength in the L grade eggs was in the range from 3275.50 as the lowest strength find in the eggs of brand 3 to $4205.20 \mathrm{~g} / \mathrm{cm}^{2}$ as higher strength monitored on the eggs of brand 5, that could be seen from the Graph 4. Out of 110 analyzed eggs from brand L, only 35 eggs, or around $30.43 \%$ meet the desired shell strength.

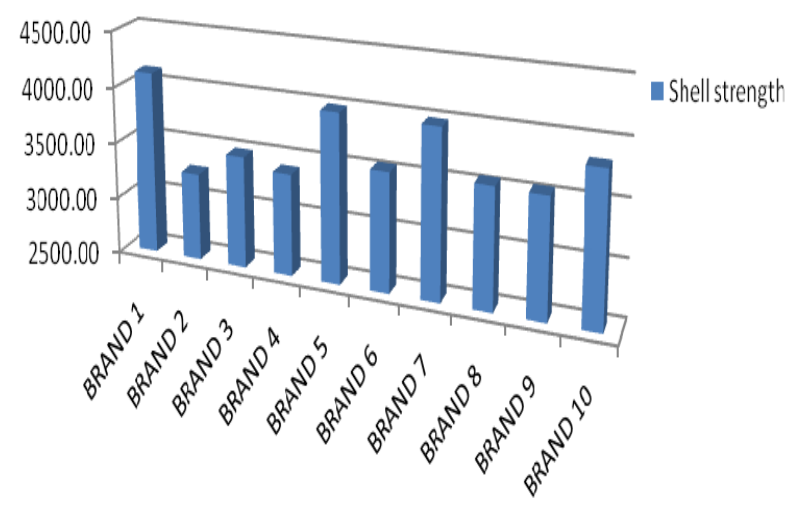

Graph. 4. Egg shell strength in M graded eggs from different brands 
Eggs graded as XL weight grade, where only 10 eggs of brands 5 and 6 were analyzed revealed significant deviations regarding declared egg weight (that for this grade should be over $73 \mathrm{~g}$ ). As could be revealed from the data in Table 3 average egg weight in this grade (brand 5) is $71.49 \mathrm{~g}$ that is lower than the minimum weight limit of $73 \mathrm{~g}$ for this grade.

It is significant to stress that in this biggest grade of eggs that is escorted or valued with the highest price in the eggs from brand 5 only 3 out of 10 eggs $(30 \%)$ were with weight higher than the minimally prescribed weight of $73 \mathrm{~g}$, or saying with other words $70 \%$ of the eggs were declared as $\mathrm{XL}$ even that according the weight they should be graded and declared as L grade eggs. In the other analysed brand (brand 6) even that average weight was over the minimal, 3 eggs out of analyzed 10 (or $30 \%$ ) were with weight under the minimal weight of $73 \mathrm{~g}$, or were eggs of L grade even that they were declared and packed as XL grade.

Shortly this means that packers or packing centers have mixed the eggs with lower weight (lower grade eggs) with the bigger (eggs of higher weight or graded as XL) ones (in the case of XL grade one of the brands (5) pack and declare $70 \%$, and the other brand (6), 30\% eggs of lower grades eggs in to this, XL grade) with only one aim to get additional profit from the sales of these eggs as eggs of higher weight grade through cheating the consumers.

In relation to the shell strength it was expected that we'll find lower values (3440.40 $3583.40 \mathrm{~g} / \mathrm{cm}^{2}$ ), because it is the highest grade with eggs with the biggest weight where increased weight and age of the hens lead to significant decrease of shell strength. In all analyzed eggs of this grade the shell strength was below the required values.

According the recommendation of [9], shell strength should be in the range of 3.85 to 4.10 $\mathrm{kg} / \mathrm{cm}^{2}$. Shell strength and thickness varies in relation to the egg weight. Authors [17] referred statistically significantly thicker shell in eggs of the middle size while thinner shell was notified in eggs declared as extra large. Older hens lay eggs with thinner shell. Reason for lower values of the shell strength notified in some producers could be finding in the explanation that the eggs are produced by flock of advanced age.

Authors [4] referred significantly negative correlations $(P<0.05)$ between egg weight and egg shell strength that confirms the theory that shell strength decreases while egg weight increases.

According the authors [12], most important thing in the production of eggs regarding the egg weight is: a) to get fast increase of the egg weight (less than 50\% eggs with weigh of $65-70 \mathrm{~g}$ at the age of 22-23 weeks), and b) to stabilize the weight starting from the age of 45 weeks (maximum 15$20 \% \mathrm{XL}$ graded eggs at the end of the laying cycle).

Low egg shell strength results with extreme high lost in eggs due to higher percent of broken and cracked eggs that lower the profit of the producers and packers of shell eggs for consumption. These losses could be as high as $3.36 \%$ out of total number of eggs produced on the farm where the age of the layers is over 45 weeks as referred by authors [10] or as published by [2] up to $6-8 \%$ and even more regarding the age and laying period.

\section{CONCLUSIONS}

Results from the analyses of the eggs graded in $\mathrm{M}, \mathrm{L}$ and $\mathrm{XL}$ weight classes, from different brands sampled from different markets showed significant manipulations or deviations from the declared values for egg size (weight in $\mathrm{g}$ ) and egg shell strength expressed in $\mathrm{g} / \mathrm{cm}^{2}$.

1. In all brands and all markets eggs from $M$ weight grade, most often correspond to declared weight that means that no discrepances are notified in the packages or that the packages do not contain eggs with weight lower than the minimal weight (size) for this grade $(53 \mathrm{~g})$. In the packages with eggs from other grades (L and XL weight grade) mixing of eggs with lower than the minimum weight for these grades is notified. More precisely packages containing $\mathrm{L}$ weight grade, contain some percent of eggs that should be graded as $\mathrm{M}$ weight grade, and in packages contain XL weight grade, some percent of L weight grade eggs are notified.

These situations (discrepances between declared and monitored weight grade) are most probably results of egg mixing, where eggs from lower grades are putted in packages containing higher weight grades. This mixing of eggs of different weight grades is probably realized by packers or packing centres or brands that are offering the eggs on the market with intention to get better price through consumer cheeting. Such fact is supported with the fact that any manipulations and mixing in the phase of distribution and sells in the markets has 
no beneficial financial effect for the market due to the definitive number of received quantities in the market in accordance with the documents of delivery, that means any manipulations can not lead to additional beneficial financial effects for the markets.

2. Shell strength as a parameter that has a great role during the transport and different manipulations with the eggs has been monitored as a parameter with insuficient value to offer solid marketing quality of the product.

Eggs graded as $\mathrm{M}$ grade eggs according the weight have only $20(26.66 \%)$ out of 75 analyzed samples that are with desired (declared by the genetic provenience) egg shell strength. Out of 110 analyzed eggs in the weight grade L, desired egg shell strength was notified only in 35 samples that represents only $30.43 \%$. Additionally, in the biggest grade (XL) none of the sampled 20 eggs has reached the desired egg shell strength.

Such low egg shell quality will produce higher percentage of broken and dirty egg, that will have negative financial effect for all the stakeholders in the value chain for fresh shell eggs for consumption.

\section{REFERENCES}

[1] Baumgartner J., Benková J., Peškovičová D.: Effect of line, age and individuality on yolk cholesterol content and some other egg quality traits in Leghorn type yolk cholesterol selected hens. XVIII European Symposium on the Quality of Poultry Meat and XII European Symposium on the Quality of Eggs and Egg Products, September 2-5. Prague, 2007, pp. 35-36.

[2] Hamilton R. M. G., Hollands K. G., Voisey B. W., Grunder A. A.: Relationship between egg shell quality and shell breakage and factors that affect shell breakage in the field.: A review. World's Poultry Science Journal 35, 177-190 (1979).

[3] Johnston S. A., Gous R. M.: Modelling the changes in the proportions of the egg components during a laying cycle. Br Poult Sci 48, 347-353 (2007).

[4] Kocevski D., N. Nikolova, A. Kuzelov: The influence of strain and age on some egg quality parameters of commercial laying hens. Biotechnology in Animal Husbandry, Belgrade-Zemun, Serbia. Vol. 27 (4), pp. 1649-1658 (2011).

[5] Kralik Zlata, Kralik Gordana, Grcević Manuela, Skrtić Z., Biazik Ewa: Comparison of consumable eggs quality of different producers, Krmiva 54, 1, 17-21 (2012).

[6] Ledvinka Z., Tůmová E., Arent E., Holoubek J., Klesalová $\mathrm{L}$. : Egg shell quality in some white-egg and brown-egg cross combinations of dominant hens. Czech J Anim Sci 45, 285-288 (2000).

[7] Law for quality of agricultural products, Addition of Law Official Gazette of R. Macedonia 2011/53, 14. 04. 2011 and Official Gazette of R. Macedonia 2012/55, 03. 05. 2012.

[8] Law for quality of agricultural products, Chapter 1, "Market organization“, Part 4 „Market organization for poultry meat and eggs", Official Gazette of R. Macedonia 2010/140, 21. 10. 2010.

[9] Management Guide Commercial Layers, 2007: http://www.hendrix-genetics.com.

[10] Nikolova Nedeljka, Pavlovski Zlatica, Milošević N., Waehner M.: Influence of heat stress and age on the percentage of calcium carbonate in egg shell and the percentage of broken and cracked eggs, submitted: 12. 2007 In: Archives of Animal Breeding, Germany, Dummerstorf 51, 4, pp. 389-396 (2008).

[11] Oloyo R. A.: Effect of age on total lipid and cholesterol of hen eggs. Indian J Anim Sci 73, 94-96 (2003).

[12] Pavlovski Zlatica, Skrbić Zdenka, Cmiljanić R., Lukić M.: Sistem garantovanog kvaliteta jaja u odnosu na propise EU i zahteve potrošača. Savremena poljoprivreda, Novi Sad, Srbija, Vol. 56, 1-2, str. 75-82 (2007).

[13] Peebles E. D., Zumwalt C. D., Doyle S. M., Gerard P. D., Latour M. A., Boyle C. R., Smith T. W.: Effects of breeder age and dietary fat source and level on broiler hatching egg characteristics. Poult Sci 79, 698-704 (2000).

[14] Rizzi C., Chiericato G. M.: Organic farming production. Effect of age on the productive yield and egg quality of hens of two commercial hybrid lines and two local breeds. Ital J Anim Sci 4, 160-162 (2005).

[15] Roberts J. R.: Factors Affecting Egg Internal Quality and Egg Shell Quality in Laying Hens. Journal of Poultry Science. 41, 161-177 (2004).

[16] Rulebook for the manner of marking of eggs for selling and eggs for incubation, marks and usage of marks, Official Gazette of R. Macedonia 2011/35, 22. 03. 2011.

[17] Sekeroglu A., Altuntas E.: Effects of egg weight on egg quality characteristics. Journal of the Science of Food and Agriculture, 89 (3), 379-383 (2009).

[18] Seuss-Baum I.: Nutritional evolution of egg components. $X I^{\text {th }}$ European Symposium on the Quality of Eggs and Egg Products Doorwerth, The Netherlands, 23-26 May 2005 (CD Symposium Proceedins), 2005.

[19] Silversides F. G., Scott T. A.: Effect of storage and layer age on quality of eggs from two lines of hens. Poult. Sci. 80, 1240-1245 (2001).

[20] Van den Brand H., Parmentier H. K., Kemp B.: Effects of housing system (outdoor vs. cages) and age of laying hens on egg characteristics. Br. Poult. Sci. 45, 745-752 (2004).

[21] Zemková L., Simeonovová J., Lichovníková M., Somerlíková K.: The effects of housing systems and age of hens on the weight and cholesterol concentration of the egg. Czech. J. Anim. Sci. 52, 110-115 (2007). 